\title{
Incorporating Financial Literacy into the Accounting Curriculum
}

\author{
K C. Rakow \\ Loyola University Chicago, krakow@luc.edu
}

Follow this and additional works at: https://ecommons.luc.edu/business_facpubs

Part of the Business Commons

\section{Author Manuscript}

This is a pre-publication author manuscript of the final, published article.

\section{Recommended Citation}

Rakow, K C.. Incorporating Financial Literacy into the Accounting Curriculum. Accounting Education, 28, 4: 384-400, 2019. Retrieved from Loyola eCommons, School of Business: Faculty Publications and Other Works, http://dx.doi.org/10.1080/09639284.2019.1578247

This Article is brought to you for free and open access by the Faculty Publications and Other Works by Department at Loyola eCommons. It has been accepted for inclusion in School of Business: Faculty Publications and Other Works by an authorized administrator of Loyola eCommons. For more information, please contact ecommons@luc.edu.

\section{c) (†) $\ominus$}

This work is licensed under a Creative Commons Attribution-Noncommercial-No Derivative Works 3.0 License. (c) Taylor \& Francis, 2019. 


\title{
Incorporating Financial Literacy into the Accounting Curriculum
}

\begin{abstract}
Financial literacy education, or the lack thereof, has received much attention in recent years. Over the past two decades, we have witnessed the dot com bubble, corporate scandals that stirred the market, and a large recession. Because many individuals turn to accountants for financial advice, it is now more important than ever for professionals to possess a strong foundation in basic financial literacy to better serve their clients. While the responsibility of financial literacy education does not lie with one institution or one individual, multiple efforts have been put in place to provide financial literacy education to the public. The purpose of this paper is to describe how financial literacy education was successfully incorporated into the accounting classroom to provide tomorrow's professionals with a strong foundation in financial literacy.
\end{abstract}

Keywords: financial literacy; personal finance; accounting education 


\section{Introduction}

The National Financial Educators Council defines financial literacy as "Possessing the skills and knowledge on financial matters to confidently take effective action that best fulfills an individual's personal, family and global community goals" (National Financial Educators Council, n.d.). However, the S\&P Global FinLit Survey found that only a third of the global population is financially literate. The United States (hereafter, US) finished as the fourteenth best country with only 57\% passing the financial literacy test (McGrath, 2015). Over the past twenty years, the global economy has witnessed the dot com bubble, corporate scandals that stirred the market, and a large recession. Add into the mix the increasing complexity of financial instruments available in the capital markets, a tough job market, and the growing amounts of personal debt, it is no wonder that individuals with a lack of basic financial knowledge often feel overwhelmed. Because many individuals turn to accountants for financial advice, it is now more important than ever for professionals to possess a strong foundation in basic financial literacy to better serve their clients. While the responsibility of financial literacy education does not lie with one institution or one individual, multiple efforts have been put in place to provide financial literacy education to the public. The purpose of this paper is to describe how I successfully incorporated financial literacy education into the accounting classroom to provide tomorrow's professionals with a strong foundation in financial literacy.

As educators, our primary goal is to prepare our students for success in their chosen fields. This is no different in accounting, but personal finance is not usually covered in the accounting curriculum. A recent review of the undergraduate curriculum at 435 universities found that only 37 offered a personal finance course as a general education elective (Crain, 2013). Martinez (2016) adds that only 19 of 3,500 undergraduate students took the personal 
finance course offered at her school. Taken together, it is safe to assume that very few students are being exposed to any financial literacy education at all. Even for students that receive some form of financial literacy education, very few change their financial behaviors (Fernandes, Lynch, \& Netemeyer, 2014). I believe that accounting professors should bear some of the responsibility in providing students with basic personal finance training due to the shift toward clients asking Certified Public Accountants (hereafter, CPAs) for help with their personal finances. The call has been made for CPAs to better train themselves to help clients with their personal finance needs (Anders \& Crawford, 2005), use young CPAs as leaders in building a financial literacy program into firm marketing strategy (Koziel, 2011), and help small businesses select and implement retirement plans that fit their respective needs (Williams, 2018). To assist in the education of young CPAs, the American Institute of Certified Public Accountants (hereafter, AICPA) created the Personal Financial Planning section that members can join to provide them with more tools and resources. However, much more exposure is needed prior to students graduating with their degrees in accounting and entering the workforce. If we are truly trying to prepare students for their careers and if providing financial advice to their clients might be a part of their career, then we must share in the burden of educating them on these topics.

Many authors have covered financial literacy, for example the book Five Minutes of Financial Literacy by Rakow and Rakow (2009). ${ }^{1}$ This text was incorporated in to the Intermediate I and II courses at a US institution to help spur discussion on financial literacy. I surveyed the students at the beginning and end of the semester and found significant improvement in their personal financial knowledge. ${ }^{2}$

\footnotetext{
${ }^{1}$ This resource was at the time available through WileyPlus. It is important to note that many different personal finance books could be used as the text to lead classroom discussions (e.g., The Money Book for the Young Fabulous and Broke by Suze Orman or Dave Ramsey's The Total Money Makeover).

${ }^{2}$ The survey was approved by my institution's Institutional Review Board.
} 
Specifically, I found that there was a statistically significant improvement on the postsurvey when compared to the scores on the pre-survey. The two sections of Intermediate I saw improvements of 17.6 percent and 22.6 percent, respectively, and the two sections of Intermediate II also saw statistically significant improvements of 31.4 percent and 29.0 percent, respectively. This supports that incorporating financial literacy topics into the course increased the students' basic financial knowledge. Additionally, students in all sections had a significant shift towards increased confidence in managing their money and felt more informed and confident about the topics covered in the respective courses. These findings are especially important considering that prior studies of financial education interventions had limited efficacy (Fernandes, Lynch \& Netemeyer, 2014), however, it is important to note that my sample of accounting and finance students might possess better financial and analytical skills than prior samples. I also find that these improvements are not driven by underlying demographic factors.

To supplement my results outside of the core accounting curriculum and to serve as a control group where topics such as investments and accounting for retirement plans are not covered in the class, I also implemented the financial literacy topics into one graduate financial accounting course within the Master of Business Administration (hereafter, MBA) program. The students were older and had more personal financial experiences, but they still significantly improved their scores on the post-survey by 6.5 percent. One interesting finding for this group is that the students in their 20's improved by a statistically significant amount, but their counterparts over the age of 30 did not. This suggests that future research on financial education might need to be altered as the students become older and have different financial experiences. Overall, the findings in the graduate course provide further evidence that students learn from the financial literacy topics covered in the course and that this is independent of the accounting 
topics covered in the course. It also suggests that significant learning is possible outside of a sample consisting only of accounting and finance students.

My study contributes to accounting education in two important ways. First, it provides an innovative approach to incorporate financial literacy, a topic largely missing from the accounting curriculum, into the classroom in a way that significantly benefits the students. Second, it answers a call from practice for accounting graduates to possess more financial literacy skills in order to better serve their clients. As such, my approach facilitates accounting graduates' ability to better help their firms meet the growing demand of personal financial advice that is being required in the accounting profession.

This paper begins by reviewing the financial literacy problems present in today's population, discussing the importance of financial literacy education for accounting students, and covering possible arguments against covering financial literacy. Next, I provide a detailed discussion of Five Minutes of Financial Literacy and how it was implemented into different courses. I then present results of student surveys completed at the beginning and end of the semester, and lastly, I conclude the paper by discussing implications of the results.

\section{The Financial Literacy Epidemic}

There exists a growing amount of evidence from both surveys and statistics that highlight how far college students are behind in their personal finance knowledge. A 2014 survey by EverFi and Higher One of over 40,000 college students found that while students are more likely to manage their own money, they are less likely to pay their credit card bills on time or pay the entire amount, follow a budget, balance their checkbook, or save and invest at least 5 percent of their income (Bidwell, 2015). An additional survey of 800 college students found that more than 
a third (37 percent) of the respondents did not pay their credit card balances off in full each month (Sallie Mae, 2016). More recently, a survey of 2,000 young adults found that 49 percent had saved less than $\$ 250$, yet they expect to retire at age 60 . This survey also found that only 3 percent would pay down their debt if they received an additional thousand dollars (Charles Schwab, 2018).

In addition to credit card debt, the average US college graduate in 2016 had $\$ 37,172$ in student loan debt, which represents a six percent increase over the prior year (Student Loan Hero, 2017). However, growing debt does not always end after graduation. Pressure to look successful after graduation has also led to an increase in student debt (Bryant, Stone, \& Weir, 2007). When you consider credit card and student loan debt together with the additional costs related to starting a career, it is of no surprise that financial issues continue and even increase after graduation.

This deficiency in personal finance knowledge does not only affect college students and recent graduates, but persists across the wider population. One study showed that the lack of personal financial education has contributed to the increase in consumer credit debt by 59.4 percent over the past decade (Federal Reserve Statistical Release, 2009). The 2016 Consumer Financial Literacy Survey found that 75 percent of adults could benefit from additional advice and answers to everyday financial questions from a professional. The survey added that 44 percent would give themselves a grade of C, D, or F on their personal finance knowledge (Harris Poll, 2016). Further, a recent study using LinkedIn members found that less than two-thirds of chief financial officers, chief executive officers, and chief operating officers completed a financial literacy test correctly (Anderson, Baker, \& Robinson, 2017). 
The reality of these statistics is especially startling considering the efforts to improve financial literacy education in the US by the AICPA, the government (e.g., President's Advisory Council on Financial Capability), numerous university programs (e.g., Texas Tech University's Red to Black Program), service learning opportunities by students (DeLaune, Rakow, \& Rakow, 2010) and curriculum designed specifically for college students (e.g., Foundations in Personal Finance by Dave Ramsey). These different groups and programs demonstrate that there are many ways to successfully increase college students' personal financial literacy. With the growing demand placed on accounting professionals to also provide personal finance guidance to their clients, all of these programs are important but more are needed. This paper provides one additional innovation in financial literacy education that reaches accounting students directly by incorporating it into the accounting curriculum.

\section{Arguments against Teaching Financial Literacy}

A common argument against covering financial literacy in class is time constraints. Many teachers, especially those who teach the demanding intermediate courses, are often pressed for time and find themselves forced to sometimes omit certain topics. If this is the case, many would argue that more optional material (e.g., financial literacy) cannot be added to the course. However, if you look at the statistics of the financial literacy of today's college students, the lack of financial literacy of the potential clients they might serve after graduation, and the fact that many CPAs are now being counted on to provide financial planning advice for their clients, I argue that financial literacy topics must be covered in some form in the accounting curriculum. Another argument against covering financial literacy in the classroom would be that the students at some schools all go to work for the largest accounting firms and will not be helping 
clients with personal finances. I have taught at large public universities where this is true, but I have also taught at a smaller private school where only one or two accounting graduates will go work at a large accounting firm. As such, the decision to incorporate financial literacy into the curriculum is institution specific. However, regardless of where young CPAs start their careers, the fact that many of them will at some point provide personal finance advice to clients remains. The AICPA points out that the majority of CPAs are providing financial planning advice already (97 percent tax planning, 62 percent estate planning, 54 percent retirement planning, and 23 percent wealth management). They add that there will be a 30 percent increase in the need for financial advisors over the next ten years and that personal financial planning services are expected to grow two times faster than traditional accounting services globally (AICPA, n.d.). This growing demand coupled with the low levels of financial literacy by the population represent a great opportunity for the accounting profession and supports the inclusion of financial literacy into the curriculum.

\section{Incorporating Financial Literacy into the Classroom}

The text used in the classroom to facilitate discussions was Five Minutes of Financial Literacy (Rakow \& Rakow, 2009) (hereafter, FMOFL). The title was derived from the idea that the material should only be supplementary in an accounting course, and no more than five minutes should be spent on it in any given class session. After an introduction that included the objectives of the text and several startling statistics, the FMOFL covers the following topics: credit scores, credit reports, credit cards, basic budgeting, buying a car, buying a home, investing, and retirement planning. The topics covered provided basic knowledge while avoiding complex details that might turn off the students. It is important to note that the goal is 
not to turn each student into a personal finance expert, but rather, provide them with a solid foundation of financial literacy. Each chapter defined the topic as well as key terms related to the topic, included important information about the topic, tips to avoid making mistakes, a Jack and Jill section that showed both good and bad behavior in each area, a pause and discuss section to spur discussion, and an action plan to encourage students to actively manage their finances.

For example, the chapter on home purchases defined what a mortgage is and provided details on two common types of mortgages (e.g., fixed rate and adjustable rate mortgages). The chapter went on to discuss important information about buying a home (e.g., closing costs, points, private mortgage insurance, and good faith estimates). Next, the chapter provided illustrations of what a mortgage payment schedule looks like by comparing the difference in interest paid over the life of a 30-year fixed rate mortgage as compared to a 15 -year fixed rate mortgage. The chapter then used a Jack and Jill example to define and show the benefits of systematic overpayment on your mortgage. The chapter concluded with several tips to avoid making mistakes with a mortgage, a pause a discuss section highlighting some of the ideas presented in the chapter, and an action plan that encourages students to find a house they would like to live in and investigate the cost and monthly payments for that house.

I chose to use the FMOFL in two semesters of Intermediate I, two semesters of Intermediate II, and one semester of the graduate Financial Accounting course. In Intermediate I, I covered credit scores, credit reports, credit cards, basic budgeting, and car purchases. In Intermediate II, I covered buying a home, investing, and retirement. The chapters covered in Intermediate II matched up with topics covered in the course. I discussed buying a home when covering the chapter on long-term liabilities, investing during the chapter on investments, and 
retirement while discussing the accounting for defined contribution and defined benefit plans. In the graduate course, all chapters were covered.

I started each semester by performing a pre-survey specific to the topics covered in that course. Appendix A includes the pre-survey for the graduate course because it included all topics. The Intermediate I and II surveys encompassed the same questions but only included those questions related to the topics covered in the course. ${ }^{3}$ The surveys have questions devoted to demographic information as well as general financial information. These questions are followed by questions specific to each topic covered during the semester from the FMOFL.

To ensure equal class participation from the students throughout the semester, groups were assigned to cover the various topics on set dates. Each group had to briefly summarize the material they covered as well as come up with questions about the material that would then be discussed as a class. The process was informal because I wanted it to be quick and spontaneous to promote better discussions. I also had pop quizzes over the material to make sure other groups were doing the assigned reading even when they were not responsible for leading the discussion. The FMOFL was not discussed every class period, and discussions were sometimes pushed back to ensure the core course material was being covered. I never wanted the FMOFL to interfere with the objectives of the course. At the end of the semester, each group turned in a financial plan for a fictitious couple with various financial issues. This assignment was designed for them to demonstrate their knowledge over all topics covered during the semester.

\footnotetext{
${ }^{3}$ The only exceptions relate to the Intermediate I and II age question was adjusted to match traditional aged college students, and the number of hours worked was adjusted to lower ranges since many of the graduate students worked full time. The Intermediate II survey also asked whether students took Intermediate I at the university and if their professor covered financial literacy in the course.
} 
To measure how much the students learned, the students also completed a post-survey. ${ }^{4}$ To ensure anonymity, all students placed their pre-surveys in an envelope with their name on the outside of the envelope at the beginning of the semester. These stayed with a graduate assistant during the semester. The post-surveys were also placed in an envelope with the students' names on the outside. The graduate student matched each student's pre-survey with their post-survey and assigned each set a number while discarding the envelopes. If a student did not complete both a pre- and post-survey, their surveys were not included in the results.

\section{SURVEY RESULTS}

\section{Intermediate I}

The FMOFL was implemented into two different semesters of Intermediate I. In the first semester, 43 out of 49 students completed both surveys, and 45 out of 55 students completed both surveys in the second semester. For the questions that relate specifically to the personal finance topics covered during the semester, there were several questions that were either right or wrong. ${ }^{5}$ This allowed me to see how many questions were answered correctly in both the preand post-surveys and to compute both a level change in scores and a percentage change (percent change $=($ post - pre $) /$ pre $)$. Table 1 summarizes the overall survey results. The results show that the students performed poorly on the pre-test. While this is alarming, it is also in line with other studies on the financial literacy of college students mentioned above.

\footnotetext{
${ }^{4}$ The following surveys and their results were used in helping form both the pre- and post-survey used in this study: American Savings Education Council and DividedWeFail.org. (2008); the Fed's Financial Quiz (Marketplace.org, 2008); Employee Benefit Research Institute 2009 Retirement Confidence Survey (Helman, Copeland, \& VanDerhei, 2009); the 2009 Consumer Financial Literacy Survey (Harris Interactive, 2009); Test Your Financial Fitness (AC Associates, 2007); the National Financial Education Questionnaire (Institute of Consumer Financial Education, 2005); the Investor Knowledge Quiz (Financial Industry Regulatory Authority, n.d.); and The JumpStart Coalition for Personal Financial Literacy (Mandel, 2008).

${ }^{5}$ The correct answers for these survey questions are in bold font within the survey in Appendix $A$.
} 
Table 1

Overall Performance Results by Semester for Intermediate I

\begin{tabular}{|l|c|c|c|c|}
\hline & Pre-Survey & Post- Survey & $\begin{array}{c}\text { Change } \\
\text { (t-value) }\end{array}$ & $\begin{array}{c}\text { \% Change } \\
\text { (Change/Pre) }\end{array}$ \\
\hline Semester 1: & & & & \\
\hline All (n=43) & 63.6 & 74.8 & $\begin{array}{c}11.2 \\
5.92 * * *\end{array}$ & $17.6 \%$ \\
\hline Semester 2: & & & & \\
\hline All (n=45) & 63.6 & 78.0 & $\begin{array}{c}14.4 \\
7.77 * *\end{array}$ & $22.6 \%$ \\
\hline
\end{tabular}

$*, * *$, and $* * *$ represent two-tailed significance at the $.10, .05$, and .01 levels, respectively.

More importantly than the pre-survey results is whether my approach to covering financial literacy improved student performance. Table 1 highlights that both groups showed statistically significant improvement on the post-survey. The first section of students improved by 17.6 percent, and the second section improved by 22.6 percent. This in itself provides evidence that the students benefitted from topics covered during the semester and significantly raised their level of financial literacy. In addition, I wanted to evaluate how performance may or may not be driven by certain demographic factors. Table 2 presents student performance based on age, gender, hours worked per week, and family class. ${ }^{6}$

Table 2

Performance Results Based on Demographics by Semester for Intermediate I

Panel A: Results by Age

\begin{tabular}{|l|c|c|c|c|}
\hline & Pre- Survey & Post- Survey & $\begin{array}{c}\text { Change } \\
\text { (t-value) }\end{array}$ & $\begin{array}{c}\text { \% Change } \\
\text { (Change/Pre) }\end{array}$ \\
\hline Semester 1: & & & & \\
\hline $19(n=3)$ & 43.9 & 61.4 & $\begin{array}{c}17.5 \\
3.78^{*}\end{array}$ & $39.9 \%$ \\
\hline $20(n=20)$ & 61.8 & 74.2 & $\begin{array}{c}12.4 \\
3.98^{* * *}\end{array}$ & $20.1 \%$ \\
\hline $21(n=11)$ & 69.4 & 78.9 & $\begin{array}{c}9.5 \\
3.77^{* * *}\end{array}$ & $13.7 \%$ \\
\hline
\end{tabular}

\footnotetext{
${ }^{6}$ It is important to note here that breaking the sample into smaller sub-groups will lead to a small number of observations within these groups. As such, the results should be interpreted with this in mind.
} 


\begin{tabular}{|c|c|c|c|c|}
\hline $22+(n=9)$ & 67.3 & 75.4 & $\begin{array}{c}8.1 \\
1.73 \\
\end{array}$ & $12.0 \%$ \\
\hline \multicolumn{5}{|c|}{ Semester 2: } \\
\hline $19(n=2)$ & 68.4 & 78.9 & $\begin{array}{l}10.5 \\
2.00\end{array}$ & $15.4 \%$ \\
\hline $20(n=19)$ & 60.7 & 78.7 & $\begin{array}{c}18.0 \\
6.96 * * *\end{array}$ & $29.7 \%$ \\
\hline $21(n=15)$ & 62.5 & 75.4 & $\begin{array}{c}12.9 \\
4.28 * * *\end{array}$ & $20.6 \%$ \\
\hline $22+(n=9)$ & 70.8 & 80.7 & $\begin{array}{c}9.9 \\
1.88 *\end{array}$ & $14.0 \%$ \\
\hline
\end{tabular}

${ }^{*}, * *$, and ${ }^{* * *}$ represent two-tailed significance at the $.10, .05$, and .01 levels, respectively.

Panel B: Results by Gender

\begin{tabular}{|c|c|c|c|c|}
\hline 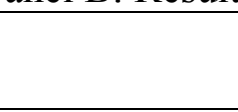 & Pre- Survey & Post- Survey & $\begin{array}{c}\text { Change } \\
\text { (t-value) }\end{array}$ & $\begin{array}{c}\text { \% Change } \\
\text { (Change/Pre) }\end{array}$ \\
\hline \multicolumn{5}{|l|}{ Semester 1: } \\
\hline$M(n=16)$ & 60.2 & 71.7 & $\begin{array}{c}11.5 \\
4.87 * * *\end{array}$ & $19.1 \%$ \\
\hline$F(n=27)$ & 65.7 & 76.6 & $\begin{array}{c}10.9 \\
4.08 * * *\end{array}$ & $16.6 \%$ \\
\hline \multicolumn{5}{|l|}{ Semester 2: } \\
\hline$M(n=23)$ & 67.7 & 78.9 & $\begin{array}{c}11.2 \\
6.06 * * *\end{array}$ & $16.5 \%$ \\
\hline$F(n=22)$ & 59.3 & 77.0 & $\begin{array}{c}17.7 \\
5.63 * * *\end{array}$ & $29.8 \%$ \\
\hline
\end{tabular}

$*, * *$, and $* * *$ represent two-tailed significance at the $.10, .05$, and .01 levels, respectively.

Panel C: Results by Hours Worked per Week

\begin{tabular}{|c|c|c|c|c|}
\hline & Pre- Survey & Post- Survey & $\begin{array}{c}\text { Change } \\
\text { (t-value) }\end{array}$ & $\begin{array}{c}\text { \% Change } \\
\text { (Change/Pre) }\end{array}$ \\
\hline \multicolumn{5}{|l|}{ Semester 1: } \\
\hline $0-9 \mathrm{hrs}(\mathrm{n}=17)$ & 64.4 & 70.6 & $\begin{array}{c}6.2 \\
2.38^{* *}\end{array}$ & $9.6 \%$ \\
\hline $10-19 \mathrm{hrs}(\mathrm{n}=11)$ & 65.6 & 78.5 & $\begin{array}{c}12.9 \\
3.30 * * *\end{array}$ & $19.7 \%$ \\
\hline $20+$ hrs $(n=15)$ & 61.4 & 76.8 & $\begin{array}{c}15.4 \\
4.85^{* * *}\end{array}$ & $25.1 \%$ \\
\hline \multicolumn{5}{|l|}{ Semester 2: } \\
\hline $0-9 \mathrm{hrs}(\mathrm{n}=15)$ & 61.4 & 75.1 & $\begin{array}{c}13.7 \\
3.36 * * *\end{array}$ & $22.3 \%$ \\
\hline $10-19$ hrs $(n=10)$ & 61.1 & 73.7 & $\begin{array}{c}12.6 \\
4.43 * * *\end{array}$ & $20.6 \%$ \\
\hline $20+h r s(n=20)$ & 66.6 & 82.4 & $\begin{array}{c}15.8 \\
6.16^{* * *}\end{array}$ & $23.7 \%$ \\
\hline
\end{tabular}

$*, * *$, and $* * *$ represent two-tailed significance at the $.10, .05$, and .01 levels, respectively. 
Panel D: Results by Family Class

\begin{tabular}{|c|c|c|c|c|}
\hline & Pre- Survey & Post- Survey & $\begin{array}{l}\text { Change } \\
\text { (t-value) }\end{array}$ & $\begin{array}{c}\text { \% Change } \\
\text { (Change/Pre) }\end{array}$ \\
\hline \multicolumn{5}{|l|}{ Semester 1: } \\
\hline $\begin{array}{l}\text { Lower/Lower } \\
\text { Middle }(n=3)\end{array}$ & 64.9 & 75.4 & $\begin{array}{l}10.5 \\
1.31\end{array}$ & $16.2 \%$ \\
\hline Middle $(n=21)$ & 61.4 & 75.7 & $\begin{array}{c}14.3 \\
4.80^{* * * *} \\
\end{array}$ & $23.3 \%$ \\
\hline $\begin{array}{l}\text { Upper Middle/ } \\
\text { Upper }(\mathrm{n}=19)\end{array}$ & 65.9 & 73.7 & $\begin{array}{c}7.8 \\
3.34^{* * * *} \\
\end{array}$ & $11.8 \%$ \\
\hline \multicolumn{5}{|l|}{ Semester 2: } \\
\hline $\begin{array}{l}\text { Lower/Lower } \\
\text { Middle (n=26) }\end{array}$ & 63.8 & 75.9 & $\begin{array}{c}12.1 \\
6.15^{* * *}\end{array}$ & $19.0 \%$ \\
\hline Middle $(n=16)$ & 63.8 & 83.6 & $\begin{array}{c}19.8 \\
8.13^{* * *} \\
\end{array}$ & $31.0 \%$ \\
\hline $\begin{array}{l}\text { Upper Middle/ } \\
\text { Upper }(\mathrm{n}=3)\end{array}$ & 61.4 & 66.7 & $\begin{array}{c}5.3 \\
0.29 \\
\end{array}$ & $8.6 \%$ \\
\hline
\end{tabular}

Panel A shows that most students are traditional college-aged students with the majority of students being either 20 or 21 years old. There appears to be significant learning across all age groups with the exception being the 22 and older group in one semester $(p$ value $=0.1219)$ and the two 19 year-olds in the second semester $(\mathrm{p}$ value $=0.2952)$. The trend appears to indicate that older students improved by smaller amounts than younger students, however, the differences between the age groups is not statistically significant with the exception that the 20 year-olds in the second semester improved by a significantly larger margin than the 22 and over group $(\mathrm{p}$ value $=0.092)$. Overall, it appears that there is learnings across the different age groups, but the amount of learning is not significantly different between age groups.

Panel B shows the results by gender. There were eleven more females than males in the first semester, but one more male in the second semester. Both males and females showed significant improvements in their scores from pre- to post-survey. Further analysis (not tabulated) reveals that the difference in improvement between males and females is not 
significant in the first semester, but the female group in the second semester improved by a significantly larger margin than the males.

In Panel C, it is clear that most of the students either worked very little at all or work more than twenty hours each week. Significant learning took place at all three levels for both semesters. Students that worked over twenty hours improved by the most in each semester, but their level of learning was not significantly greater than the other two groups. Lastly, Panel D shows the results based on how the students identified their family class while growing up. While the results are inconsistent across semesters, significant learning took place for the majority of the students.

Overall, Table 2 shows that the students benefitted from the material covered during the semester and were able to significantly improve their scores on the post-survey. Also, there does not appear to be one demographic factor that drives the results even though some demographic sub-groups perform better than others. For example, the 20 year-old group in the second semester performed better than their 22 and over counterparts, but this was not the case for the first semester. Additionally, the female group in the second semester improved by a significantly larger margin than the males, but this did not occur in the first semester. To further explore this, I perform a simple regression analysis (not tabulated) to see if demographic differences are driving the improvements in post-surveys. The results are once again mixed between semesters with only Gender being significant in the first semester and Age being marginally significant in the second semester. These mixed results further support that a single demographic characteristic is not driving the results and that a significant level of learning is taking place across my sample. 
When looking at the general financial questions on the survey, students who were less confident in managing their money to achieve their financial goals (Question 6) on the presurvey improved the most on the post-survey. The one exception to this is for the three students from one semester who answered that they were fully confident on the pre-survey actually had the highest level of improvement on the post-survey suggesting that maybe they were overconfident. However, this highlights the importance of incorporating financial literacy topics in the classroom because even those students who think they already understand the various financial issues that might arise can still learn and benefit from the material covered during the semester. Table 3 shows the difference in levels of confidence between the pre- and postsurveys for both semesters combined. The results indicate a statistically significant shift towards students being more confident in managing their money to reach their financial goals.

Table 3

Stated Level of Confidence in Managing Money to Achieve Financial Goals for Students in Intermediate I on Pre- and Post-Surveys ( $1=$ Least Confident and 7=Most Confident)

\begin{tabular}{|c|c|c|}
\hline $\begin{array}{c}\text { Confidence } \\
\text { Level }\end{array}$ & $\begin{array}{c}\text { Pre- } \\
\text { Survey }\end{array}$ & $\begin{array}{c}\text { Post- } \\
\text { Survey }\end{array}$ \\
\hline 1 & 0 & 0 \\
\hline 2 & 1 & 0 \\
\hline 3 & 12 & 1 \\
\hline 4 & 17 & 10 \\
\hline 5 & 35 & 38 \\
\hline 6 & 14 & 34 \\
\hline 7 & 9 & 5 \\
\hline Mean & 4.86 & 5.36 \\
\hline $\begin{array}{c}\text { Change } \\
\text { (t-value) }\end{array}$ & \multicolumn{2}{|c|}{0.50} \\
$4.51^{* * *}$ \\
\hline *** represents two-tailed significance at the .01 level.
\end{tabular}

Students in both semesters (Question 8) felt that advancing their career or earning more money and receiving a higher education or degree were the most important goals over the next ten years. Items such as living a more spiritual life, paying off debt, preparing for a child's 
education and starting and growing a business were not goals. On the surface, the fact that paying off debt was not a goal was somewhat concerning. However, when combing this with the fact that both sets of students had little to no debt (Question 12), it was easier to understand why it was not a goal.

When comparing between the pre- and post-surveys about how knowledgeable students are to various items (Question 9), the knowledge level increased in almost every area even if it was not covered specifically in class. Additionally, the number of students who said they stick to a monthly budget increased by seven overall, and the number who said they now have a formal, written financial plan increased by six overall. The increase in students sticking to a budget and developing a financial plan are both tangible benefits of the materials covered in the course.

\section{Intermediate II}

I also implemented the FMOFL into two different semesters of Intermediate II. In the first semester, 66 out of 77 students completed both surveys, and 64 out of 76 students completed both surveys in the second semester. Table 4 shows the overall results for both semesters of Intermediate II students. Both semesters improved by statistically significant margins on the post-survey. The first section of 66 students improved by 31.4 percent, and the second section of 64 students improved by 29.0 percent. Consistent with Intermediate I, this in itself implies that the students benefitted from topics covered during the semester and significantly raised their level of financial literacy. The much lower pre-survey scores and much larger percent improvement as compared to Intermediate I can be attributable to the fact that the topics covered in Intermediate II (Home Ownership, Investing, and Retirement) are topics that most students 
have less exposure to than topics such as Budgeting and Credit Cards that are covered in Intermediate I.

Table 4

Overall Performance Results by Semester for Intermediate II

\begin{tabular}{|l|c|c|c|c|}
\hline & Pre-Survey & Post- Survey & $\begin{array}{c}\text { Change } \\
\text { (t-value) }\end{array}$ & $\begin{array}{c}\text { \% Change } \\
\text { (Change/Pre) }\end{array}$ \\
\hline Semester 1: & & & & \\
\hline All (n=66) & 52.6 & 69.1 & $\begin{array}{c}16.5 \\
9.50 * * *\end{array}$ & $31.4 \%$ \\
\hline Semester 2: & & & & \\
\hline All (n=64) & 54.2 & 69.9 & $\begin{array}{c}15.7 \\
9.97 * * *\end{array}$ & $29.0 \%$ \\
\hline
\end{tabular}

$*, * *$, and $* * *$ represent two-tailed significance at the $.10, .05$, and .01 levels, respectively.

The students in Intermediate II were also asked if they took Intermediate I at the university and if their instructor covered any financial literacy topics. All but three of the students took Intermediate I at the university, and 44 in each section had been exposed to financial literacy topics in Intermediate I. Table 5 summarizes how prior exposure to financial literacy topics affected performance.

Table 5

Performance Results (Percent Change from Pre- to Post-Survey) of Intermediate II Students Conditional on if Students had Prior Exposure to Financial Literacy Topics in Intermediate I

\begin{tabular}{|c|c|c|c|c|}
\hline & Pre- Survey & Post- Survey & $\begin{array}{c}\text { Change } \\
\text { (t-value) }\end{array}$ & $\begin{array}{c}\text { \% Change } \\
\text { (Change/Pre) }\end{array}$ \\
\hline \multicolumn{5}{|l|}{ Semester 1: } \\
\hline Yes $(n=44)$ & 53.6 & 69.0 & $\begin{array}{c}15.4 \\
7.40^{* * * *}\end{array}$ & $28.7 \%$ \\
\hline $\begin{array}{l}\text { No/Elsewhere } \\
(\mathrm{n}=22)\end{array}$ & 50.5 & 69.1 & $\begin{array}{c}18.6 \\
5.92 * * *\end{array}$ & $36.8 \%$ \\
\hline \multicolumn{5}{|l|}{ Semester 2: } \\
\hline Yes $(n=44)$ & 54.3 & 69.9 & $\begin{array}{c}15.6 \\
7.94 * * *\end{array}$ & $28.7 \%$ \\
\hline $\begin{array}{l}\text { No/Elsewhere } \\
(\mathrm{n}=20)\end{array}$ & 53.9 & 70.0 & $\begin{array}{c}16.1 \\
5.98 * * *\end{array}$ & $29.9 \%$ \\
\hline
\end{tabular}


Overall, there is significant improvement regardless of their prior exposure. While the students without prior exposure to financial literacy topics had lower pre-survey scores and improved by more than those with prior exposure, the differences between the groups are not significantly different. Consistent with the Intermediate I course, I also present the results based on different demographics in Table 6.

Table 6

Overall Performance Results by Semester for Intermediate II

Panel A: Results by Age

\begin{tabular}{|c|c|c|c|c|}
\hline (2) & Pre- Survey & Post- Survey & $\begin{array}{c}\text { Change } \\
\text { (t-value) }\end{array}$ & $\begin{array}{c}\text { \% Change } \\
\text { (Change/Pre) }\end{array}$ \\
\hline \multicolumn{5}{|l|}{ Semester 1: } \\
\hline $19(n=3)$ & 28.1 & 56.1 & $\begin{array}{c}28.0 \\
8.00 * *\end{array}$ & $99.6 \%$ \\
\hline $20(n=15)$ & 44.9 & 64.9 & $\begin{array}{c}20.0 \\
6.38 * * * \\
\end{array}$ & $44.5 \%$ \\
\hline $21(n=31)$ & 53.8 & 69.8 & $\begin{array}{c}16.0 \\
6.08 * * *\end{array}$ & $29.7 \%$ \\
\hline $22+(n=17)$ & 61.3 & 73.7 & $\begin{array}{c}12.4 \\
3.43^{* * *}\end{array}$ & $20.2 \%$ \\
\hline \multicolumn{5}{|l|}{ Semester 2: } \\
\hline $19(n=3)$ & 63.2 & 77.2 & $\begin{array}{c}14.0 \\
3.02 *\end{array}$ & $22.2 \%$ \\
\hline $20(n=20)$ & 49.7 & 67.9 & $\begin{array}{c}18.2 \\
5.55^{* * *}\end{array}$ & $36.6 \%$ \\
\hline $21(n=23)$ & 50.6 & 68.4 & $\begin{array}{c}17.8 \\
7.36 * * * \\
\end{array}$ & $35.2 \%$ \\
\hline $22+(n=18)$ & 62.3 & 72.8 & $\begin{array}{c}10.5 \\
4.01 * * *\end{array}$ & $16.9 \%$ \\
\hline
\end{tabular}

$*, * *$, and ${ }^{* * *}$ represent two-tailed significance at the $.10, .05$, and .01 levels, respectively.

Panel B: Results by Gender

\begin{tabular}{|l|c|c|c|c|}
\hline & Pre- Survey & Post- Survey & $\begin{array}{c}\text { Change } \\
\text { (t-value) }\end{array}$ & $\begin{array}{c}\text { \% Change } \\
\text { (Change/Pre) }\end{array}$ \\
\hline Semester 1: & & & & \\
\hline M (n=31) & 61.0 & 75.2 & $\begin{array}{c}14.2 \\
5.72 * * *\end{array}$ & $23.3 \%$ \\
\hline F (n=35) & 45.1 & 63.6 & $\begin{array}{c}18.5 \\
7.69 * * *\end{array}$ & $41.0 \%$ \\
\hline
\end{tabular}




\begin{tabular}{|l|c|c|c|c|}
\hline Semester 2: & & & & \\
\hline $\mathrm{M}(\mathrm{n}=26)$ & 58.7 & 72.5 & $\begin{array}{c}13.8 \\
6.60 * * *\end{array}$ & $23.5 \%$ \\
\hline $\mathrm{F}(\mathrm{n}=38)$ & 51.1 & 68.1 & $\begin{array}{c}17.0 \\
7.63 * *\end{array}$ & $33.3 \%$ \\
\hline
\end{tabular}

$*, * *$, and ${ }^{* * *}$ represent two-tailed significance at the $.10, .05$, and .01 levels, respectively.

Panel C: Results by Hours Worked per Week

\begin{tabular}{|c|c|c|c|c|}
\hline & Pre- Survey & Post- Survey & $\begin{array}{c}\text { Change } \\
\text { (t-value) }\end{array}$ & $\begin{array}{c}\text { \% Change } \\
\text { (Change/Pre) }\end{array}$ \\
\hline \multicolumn{5}{|l|}{ Semester 1: } \\
\hline $0-9 \mathrm{hrs}(\mathrm{n}=25)$ & 53.1 & 69.3 & $\begin{array}{c}16.2 \\
5.26 * * *\end{array}$ & $30.5 \%$ \\
\hline 10-19hrs $(\mathrm{n}=18)$ & 47.4 & 69.3 & $\begin{array}{c}21.9 \\
8.23 * * *\end{array}$ & $46.2 \%$ \\
\hline $20+h r s(n=23)$ & 56.1 & 68.6 & $\begin{array}{c}12.5 \\
4.37 * * *\end{array}$ & $22.3 \%$ \\
\hline \multicolumn{5}{|l|}{ Semester 2: } \\
\hline $0-9$ hrs $(\mathrm{n}=28)$ & 56.2 & 71.4 & $\begin{array}{c}15.2 \\
6.75^{* * * *}\end{array}$ & $27.0 \%$ \\
\hline $10-19$ hrs $(n=20)$ & 51.3 & 65.8 & $\begin{array}{c}14.5 \\
4.74 * * *\end{array}$ & $28.3 \%$ \\
\hline $20+$ hrs $(n=16)$ & 54.3 & 72.4 & $\begin{array}{c}18.1 \\
5.62 * * *\end{array}$ & $33.3 \%$ \\
\hline
\end{tabular}

$*, * *$, and $* * *$ represent two-tailed significance at the $.10, .05$, and .01 levels, respectively.

Panel D: Results by Family Class

\begin{tabular}{|l|c|c|c|c|}
\hline & Pre- Survey & Post- Survey & $\begin{array}{c}\text { Change } \\
\text { (t-value) }\end{array}$ & $\begin{array}{c}\text { \% Change } \\
\text { (Change/Pre) }\end{array}$ \\
\hline Semester 1: & & & & \\
\hline $\begin{array}{l}\text { Lower/Lower } \\
\text { Middle (n=9) }\end{array}$ & 43.9 & 66.7 & $\begin{array}{c}22.8 \\
5.31^{* * *}\end{array}$ & $51.9 \%$ \\
\hline Middle (n=23) & 50.8 & 69.6 & $\begin{array}{c}18.8 \\
6.84^{* * *}\end{array}$ & $37.0 \%$ \\
\hline $\begin{array}{l}\text { Upper Middle/ } \\
\text { Upper (n=34) }\end{array}$ & 56.0 & 69.3 & $\begin{array}{c}13.3 \\
5.33^{* * *}\end{array}$ & $23.8 \%$ \\
\hline Semester 2: & & & & 14.5 \\
\hline $\begin{array}{l}\text { Lower/Lower } \\
\text { Middle (n=4) }\end{array}$ & 48.7 & 63.2 & $3.67^{* *}$ & $29.8 \%$ \\
\hline Middle (n=29) & 56.6 & 71.0 & $\begin{array}{c}14.4 \\
5.61 * * *\end{array}$ & $25.4 \%$ \\
\hline $\begin{array}{l}\text { Upper Middle/ } \\
\text { Upper (n=31) }\end{array}$ & 52.6 & 69.8 & $\begin{array}{c}17.2 \\
7.91^{* * *}\end{array}$ & $32.7 \%$ \\
\hline
\end{tabular}

$*{ }^{* *}$, and ${ }^{* * *}$ represent two-tailed significance at the $.10, .05$, and .01 levels, respectively. 
In Panel A, most students are traditional college-aged students with the majority of students being either 20 or older. There is significant learning across all age groups with the trend indicating that younger students appear to improve by more than the older students, especially for the first semester. Further analysis (not tabulated) shows that in the first semester, the 19 year-old group's level of change was significantly more than both the 21 year-old and 22 and over groups, and the 20 year-old group improved by a significantly greater margin than the 22 and over group. In the second semester, only the 20 year-old group improved by a significantly greater margin than the 22 and over group. Consistent with Intermediate I, learning is taking place at all age levels with the trend of younger students improving by more than older students being more prominent in Intermediate II as harder financial literacy topics are covered.

Panel B shows the results by gender. There were more females than males in both semesters. Both showed significant improvements in their scores from pre- to post-survey, with the females experiencing more improvement. Additional analysis (not tabulated) shows that females improved by a significantly greater margin than males in both semesters. Taken together with the results from Intermediate I, females improved by a significantly greater margin in three out of the four semesters surveyed.

The amount of hours worked by the students, Panel C, seems more evenly spread out when compared to Intermediate I. Significant improvement took place across all ranges of hours worked, but like Intermediate I, there does not appear to be a real trend in the data for hours worked per week. Panel D shows significant learning took place regardless of family class while growing up, but similar to Intermediate I, the results are inconsistent across semesters.

Overall and consistent with Intermediate I, Table 6 shows that the students benefitted from the material covered during the semester and were able to significantly improve their scores 
on the post-survey. Unlike Intermediate I, there appears to be more prominent trends in the results when looking at the different demographic sub-groups. For example, younger students improved by greater margins than the older students, and females improved by a greater amount than their male counterparts. I next perform a simple regression (not tabulated) to see if demographic differences are driving the improvements seen in the survey scores. Similar to Intermediate I, the results are mixed across semesters with only Age being significant in the first semester, and no variables in the second semester are significantly related to the improvements in survey scores. Taken together with Intermediate I results, there does not appear to be a single demographic factor driving the improvement in survey scores, which suggests that all students are benefiting from the coverage of the material in class.

When looking at students and their confidence in managing money to achieve their financial goals (Question 6), there was no clear trend despite improvement taking place at each level of confidence. Once again, this highlights the importance of incorporating financial literacy topics in the classroom because even those students that were more confident on the presurvey can still learn and benefit from the material covered during the semester. Table 7 shows the difference in levels of confidence between the pre- and post-surveys for both semesters combined. While there is a statistically significant shift to higher confidence for the students, it is interesting that only one student selected the highest level of confidence in the post-survey. I think this is an important result because it suggests that the students, many who have taken two semesters of intermediate with financial literacy topics incorporated into both semesters, now realize that they have a good foundation of knowledge but still have a lot to learn before being fully confident. 
Table 7

Stated Level of Confidence in Managing Money to Achieve Financial Goals for Students in Intermediate II on Pre- and Post-Surveys ( $1=$ Least Confident and 7=Most Confident)

\begin{tabular}{|c|c|c|}
\hline $\begin{array}{c}\text { Confidence } \\
\text { Level }\end{array}$ & $\begin{array}{c}\text { Pre- } \\
\text { Survey }\end{array}$ & $\begin{array}{c}\text { Post- } \\
\text { Survey }\end{array}$ \\
\hline 1 & 0 & 0 \\
\hline 2 & 3 & 1 \\
\hline 3 & 11 & 7 \\
\hline 4 & 30 & 17 \\
\hline 5 & 67 & 69 \\
\hline 6 & 13 & 35 \\
\hline 7 & 6 & 1 \\
\hline Mean & 4.72 & 5.04 \\
\hline $\begin{array}{c}\text { Change } \\
\text { (t-value) }\end{array}$ & \multicolumn{2}{|c|}{0.32} \\
*** represents two-tailed significance at the .01 level.
\end{tabular}

Students in both semesters (Question 8) felt that putting money away for retirement, advancing their career or earning more money, and receiving a higher education or degree were the most important goals over the next ten years. The addition of saving for retirement as a goal is a positive sign that the financial literacy topics covered in Intermediate II taught the students the importance of planning for your future and starting early. Similar to Intermediate I, items such as living a more spiritual life, paying off debt, preparing for a child's education and starting and growing a business were not goals.

When comparing between the pre- and post-surveys about how knowledgeable students are to various items (Question 9), the knowledge level for topics covered in Intermediate I (eliminating/avoiding debt, buying a car, and how to stick to a budget) were all chosen as the items where the students felt they had the most knowledge on the pre-survey. The knowledge level for items related to topics covered in Intermediate II (buying a home, saving for retirement, and investing) all increased in the post-survey. This provides further support that the students benefitted from the financial literacy topics covered. 
On the pre-survey, most students said they did have a savings account, but they had either thought some or not too much about retirement, had not saved any for retirement, and will not have enough money at retirement. Because retirement and investing were both covered in Intermediate II, the post-survey shows that the students had now thought much more about retirement and believe they will be able to save enough for retirement. While I did not expect the entire class to open a retirement account, eight more students said they had started saving for retirement on the post-survey than was stated on the pre-survey. I consider this another indication of the success of the implementation of the financial literacy topics in the course and highlights the tangible benefits the material provided the students.

Taking the results from both Intermediate I and II together, it is evident that the process by which the financial literacy topics were implemented into the course clearly benefitted the students. Their knowledge on the topics covered increased significantly, and most importantly, provided them with a solid foundation to further their financial literacy after these two courses.

\section{Supplemental Analysis}

To provide further evidence on the level of financial literacy within my student population and on the effect of the financial literacy teachings, I also incorporated financial literacy into one graduate accounting courses. By doing this, I provide a unique sample to compare my other results. This sample is unique because the students are not necessarily accounting or finance majors, are older students (only five of the 44 students said they were in the 22-25 age range with the rest being older), and have more life and financial experiences. ${ }^{7}$ This group of students also serves as a control group to counter the argument that students improved only because some of the financial literacy topics covered were also accounting topics

\footnotetext{
${ }^{7}$ For this course, 44 out of 47 students completed both surveys.
} 
covered (e.g., retirement planning was discussed while covered accounting for retirement plans in the course).

The graduate students did much better on the pre-survey (overall average of 72.6 percent) but still improved overall by 6.5 percent on the post-survey, which was a significant improvement $(\mathrm{p}$ value $=0.0011)$. Another important reason to teach financial literacy is the fact these are all students pursing a graduate degree in business and they still scored in the low 70's on basic personal finance questions. Some interesting results (not tabulated) show that the students still in their 20's showed significant improvement on their post-surveys, while the students that are in their 30's did not. This is not surprising considering the older students have more than likely been exposed to home purchases, car loans, retirement savings, etc. Both males and females had significant levels of improvement, but there is no difference between genders. All students worked over 40 hours per week, and significant learning took place regardless of family class.

While goals such as advancing their career or receiving a higher education were also important to this group, goals like more leisure travel time and paying off debt were ranked highly as goals by this group of students. One important finding is that the vast majority of these graduate students did not have a written financial plan, will, or living will. Perhaps future efforts on teaching financial literacy should stress the importance of at least some estate planning, especially considering that 62 percent of CPAs are already providing estate planning advice to clients (AICPA, n.d.). Overall, despite this sample of students having more exposure to the financial literacy topics covered during the course, they still significantly improved their knowledge of the material.

\section{Conclusion}


As the services that accounting professionals provide continue to evolve, the profession has noticed an increase in the amount of financial planning advice given by its members. While this is an expanding role for most in the accounting profession, it also provides a unique opportunity for professionals to further connect with their clients. As educators, we must put our students into a position to seize these new opportunities, but very little is being done to educate students about personal finance. While the statistics on financial literacy for college students and the broader population are troubling, several efforts exist that hope to increase students' level of financial literacy. This paper is one example of how to successfully implement financial literacy topics into the accounting curriculum in a manner that is efficient, significantly benefits the students, and helps prepare them to seize these new opportunities in the accounting profession. 


\section{REFERENCES}

AC Associates. (2007, May 20). Test Your Financial Fitness. Retrieved from http://acassociatesusa.blogspot.com/2007/05/test-your-financial-fitness.html.

American Institute of Certified Public Accountants. (n.d.) The CPA Financial Planner - Facts and Opportunities. Retrieved from https://www.aicpa.org/interestareas/personalfinancialplanning/cpa-financial-planner.html.

American Savings Education Council \& DividedWeFail.org. (2008). Preparing for Their Future: A Look at the Financial State of Gen X and Gen Y. Retrieved from http://www.choosetosave.com/pdf/preparing.pdf?cv=1\&session$\underline{\mathrm{id}=\mathrm{a} 5736 \mathrm{a} 95 \mathrm{e} 73 \mathrm{e} 409208 \mathrm{~d} 814 \mathrm{da} 9840 \mathrm{aebd} .}$

Anders, S. B. \& T. M. Crawford. (2005). Financial Literacy: CPAs Can Make a Difference. The CPA Journal, 75 (9), 6-9.

Anderson, A., F. Baker, \& D.T. Robinson. (2017). Precautionary Savings, Retirement Planning and Misperceptions of Financial Literacy. Journal of Financial Economics, 126 (2), 382398.

Bidwell, A. (2015, April 2). Survey: College Students Becoming Less Financially Responsible. US News. Retrieved from https://www.usnews.com/news/blogs/datamine/2015/04/02/college-students-becoming-less-financially-responsible-study-says.

Bryant, S. M., Stone, D. N., \& Wier, B. (2007). Reducing materialism through financial literacy. The CPA Journal, 78 (2), 12-14.

Charles Schwab and Co. (2018). Young Adult Financial Literacy Survey. Retrieved from: https://www.aboutschwab.com/images/uploads/inline/Schwab_2018_Young_Adult_Fina ncial_Literacy_Report_deck_0818-8ES4.pdf.

Crain, S. J. (2013). Are Universities Improving Student Financial Literacy? A Study of General Education Curriculum. Journal of Financial Education, 39 (1/2), 1-18.

DeLaune, L.D., J.S. Rakow, \& K.C. Rakow. (2010). Teaching Financial Literacy in a CoCurricular Service-Learning Model. Journal of Accounting Education, 28 (2), 103-113.

Federal Reserve Statistical Release. (2009). Consumer Credit Outstanding. Retrieved from http://www.federalreserve.gov/releases/G19/hist/cc_hist_sa.html.

Fernandes, D., J.G. Lynch Jr., \& R.G. Netemeyer. (2014). Financial Literacy, Financial Education, and Downstream Financial Behaviors. Management Science, 60 (8), 18611883. 
Financial Industry Regulatory Authority. (n.d). Investor Knowledge Quiz. Retrieved from http://www.finra.org/investors/investor-knowledge-quiz.

Harris Interactive. (2009). The 2009 Consumer Financial Literacy Survey. Retrieved from https://www.nfcc.org/wp-content/uploads/2014/04/2009FinancialLiteracySurvey.pdf.

Harris Poll. (2016). The 2016 Consumer Financial Literacy Survey. Retrieved from https://nfcc.org/wp-content/uploads/2016/04/NFCC_BECU_2016-FLS_datasheet-withkey-findings_041516.pdf.

Helman, R., C. Copeland \& J. VanDerhei. (2009, April). The 2009 Retirement Confidence Survey: Economy Drives Confidence to Record Lows; Many Looking to Work Longer. Retrieved from https://www.ebri.org/pdf/briefspdf/EBRI_IB 4-2009_RCS2.pdf.

Institute of Consumer Financial Education. (2005). National Financial Education Questionnaire. Retrieved from http://financial-educationicfe.org/financial_news_press_releases/2005/20050404_april_is_national_financial_literac y_month_free_powerpoint_show_available.asp.

Koziel, M. (2011). Business Development Skill Builders for Young CPAs. Journal of Accountancy. May 2011: 20-23.

Mandel, L. (2008). The Financial Literacy of Young American Adults: Results of the 2008 National Jump\$tart Coalition Survey of High School Seniors and College Students. Washington D.C.: The Jump\$tart Coalition for Personal Financial Literacy. Retrieved from http://jumpstart.org/assets/files/2008SurveyBook.pdf.

Marketplace.org. (2008, April 11). The Fed's Financial Quiz. Retrieved from https://www.marketplace.org/2008/04/11/life/feds-financial-quiz.

Martinez, V. (2016). Financial Literacy Among our Students: Assessing and Improving Their Knowledge. Journal of Financial Education, 42 (3/4), 291-303.

McGrath, M. (2015, November 18). A Global Financial Literacy Test Finds That Just 57\% of Adults in U.S. Are Financially Literate. Retrieved from https://www.forbes.com/sites/maggiemcgrath/2015/11/18/in-a-global-test-of-financialliteracy-the-u-s/\#1bd1910c58f0.

National Financial Educators Council. (n.d). Financial Literacy Definition. Retrieved from https://www.financialeducatorscouncil.org/financial-literacy-definition/.

Rakow, J. \& K. Rakow. (2009). Five Minutes of Financial Literacy: A Guide for College Students. Hoboken: John Wiley \& Sons, Inc. 2009. 
Sallie Mae Bank. (2016). Majoring in Money: How American College Students Manage Their Finances. Retrieved from http://news.salliemae.com/sites/salliemae.newshq.businesswire.com/files/doc library/file /SallieMae_MajoringinMoney_2016.pdf.

Student Loan Hero. (2017, March 10). A Look at the Shocking Student Debt Statistics for 2017. Retrieved from https://studentloanhero.com/student-loan-debt-statistics/.

Williams, J. (2018). Help Small Businesses Choose the Right Employee Retirement Plans. Journal of Accountancy. February 2018: 15-19. 


\section{APPENDIX A \\ Financial Literacy Pre-Survey \\ Graduate Financial Accounting}

NOTE: If the survey question contains a correct answer, the correct answer is in bold font. The graduate students received the entire survey. Intermediate I students answered the demographic and general financial sections as well as the sections on credit, budgeting, and car purchases. Intermediate II students answered the demographic and general financial sections as well as the sections on home ownership, investing, and retirement.

Demographic Information

1. What is your age?

Under 22

$22-25$

26-29

30-33

34 or greater

2. Gender

Male

Female

3. Approximately how many hours per week do you work?

Less than 20 hours per week

20 to 29 hours per week

30 to 39 hours per week

40 to 49 hours per week

50 or more hours per week

4. When you were growing up, how would you describe your family's lifestyle?

Upper class

Upper middle class

Middle class

Lower middle class

Lower class

5. I was taught personal financial literacy during my undergraduate program

Yes No 


\section{General Financial Information}

6. I am confident in managing money to achieve my financial goals

$$
\begin{array}{lllllll}
1 & 2 & 3 & 4 & 5 & 6 & 7
\end{array}
$$

No Confidence $\quad$ Fully Confident

7. How do you feel about your current financial situation?

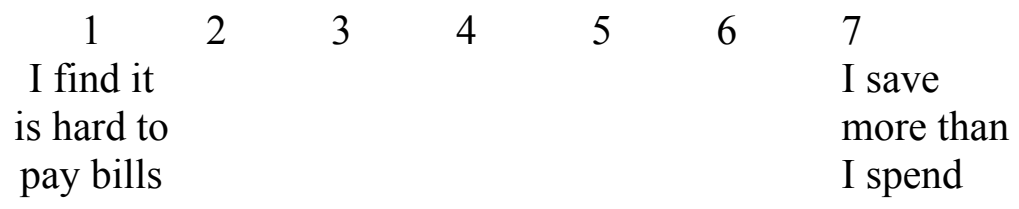

8. In the first column, please check whether each of the following is a goal of yours over the next ten years. If more than one goal is selected, please fill out the other three columns ranking the top three goals (please mark only one per column for the last three columns)

\begin{tabular}{|l|l|l|l|l|l|}
\hline \multicolumn{1}{|c|}{ Item } & $\begin{array}{c}\text { This is a } \\
\text { Goal }\end{array}$ & $\begin{array}{c}\text { Most } \\
\text { Important }\end{array}$ & $\begin{array}{c}\text { Second Most } \\
\text { Important } \\
\text { If 2 or more } \\
\text { selected) }\end{array}$ & $\begin{array}{c}\text { Third Most } \\
\text { Important } \\
\text { (If 3 or more } \\
\text { selected }\end{array}$ \\
\hline A & Getting married & & & & \\
\hline B & $\begin{array}{l}\text { Advancing your career } \\
\text { or earning more money }\end{array}$ & & & & \\
\hline C & $\begin{array}{l}\text { Buying a home or } \\
\text { making major } \\
\text { improvements to your } \\
\text { home }\end{array}$ & & & & \\
\hline D & $\begin{array}{l}\text { Doing more leisure } \\
\text { traveling }\end{array}$ & & & & \\
\hline E & Focusing on your health & & & & \\
\hline F & $\begin{array}{l}\text { Having children or } \\
\text { having more children }\end{array}$ & & & & \\
\hline G & $\begin{array}{l}\text { Living a more spiritual } \\
\text { life }\end{array}$ & & & & \\
\hline H & $\begin{array}{l}\text { Minimizing stress in } \\
\text { your life }\end{array}$ & & & & \\
\hline I & $\begin{array}{l}\text { Paying basic bills in full } \\
\text { and on time }\end{array}$ & & & & \\
\hline J & Paying off debt & & & & \\
\hline K & $\begin{array}{l}\text { Putting away money for } \\
\text { retirement }\end{array}$ & & & & \\
\hline L & $\begin{array}{l}\text { Preparing for a child's } \\
\text { education }\end{array}$ & & & & \\
\hline M & Purchasing a car & & & & \\
\hline
\end{tabular}




\begin{tabular}{|l|l|l|l|l|l|}
\hline N & $\begin{array}{l}\text { Receiving a higher } \\
\text { education or degree for } \\
\text { yourself }\end{array}$ & & & & \\
\hline O & Start or grow a business & & & & \\
\hline P & Something else & & & & \\
\hline Q & Not sure / none of these & & & & \\
\hline
\end{tabular}

9. How knowledgeable do you feel when it comes to.....?

\begin{tabular}{|c|c|c|c|c|c|}
\hline & Item & $\begin{array}{c}\text { Very } \\
\text { Knowledgeable }\end{array}$ & $\begin{array}{c}\text { Somewhat } \\
\text { Knowledgeable }\end{array}$ & $\begin{array}{c}\text { Not Too } \\
\text { Knowledgeable }\end{array}$ & $\begin{array}{c}\text { Not At All } \\
\text { Knowledgeable }\end{array}$ \\
\hline A & $\begin{array}{l}\text { Eliminating } \\
\text { /avoiding debt }\end{array}$ & & & & \\
\hline B & $\begin{array}{l}\text { Buying a } \\
\text { home }\end{array}$ & & & & \\
\hline $\mathrm{C}$ & $\begin{array}{l}\text { Saving for } \\
\text { retirement }\end{array}$ & & & & \\
\hline $\mathrm{D}$ & Buying a car & & & & \\
\hline $\mathrm{E}$ & $\begin{array}{l}\text { Doing your } \\
\text { taxes }\end{array}$ & & & & \\
\hline $\mathrm{F}$ & $\begin{array}{l}\text { How the } \\
\text { Social } \\
\text { Security } \\
\text { system works }\end{array}$ & & & & \\
\hline G & $\begin{array}{l}\text { How to stick } \\
\text { to a budget }\end{array}$ & & & & \\
\hline $\mathrm{H}$ & $\begin{array}{l}\text { How to invest } \\
\text { your money } \\
\text { outside of the } \\
\text { workplace }\end{array}$ & & & & \\
\hline $\mathrm{I}$ & $\begin{array}{l}\text { How to use an } \\
\text { ipod }\end{array}$ & & & & \\
\hline
\end{tabular}

10. To the best of your knowledge, do you think it is easier or harder for people in your generation to do each of the following than it was for your parents' generation?

\begin{tabular}{|l|l|l|l|l|}
\hline \multicolumn{1}{|c|}{ Item } & $\begin{array}{c}\text { Easier for your } \\
\text { generation }\end{array}$ & Same & $\begin{array}{c}\text { Harder for } \\
\text { your } \\
\text { generation }\end{array}$ \\
\hline A & Buying a first home & & & \\
\hline B & Finding good employment & & & \\
\hline C & Getting an education & & & \\
\hline
\end{tabular}




\begin{tabular}{|l|l|l|l|l|}
\hline D & Supporting a family & & & \\
\hline E & $\begin{array}{l}\text { Saving money for the long- } \\
\text { term }\end{array}$ & & & \\
\hline F & $\begin{array}{l}\text { Saving for a child's college } \\
\text { education }\end{array}$ & & & \\
\hline
\end{tabular}

11. Do you expect to provide some sort of financial support to your parents during their retirement?

Yes $\quad$ No Not Sure

12. Do you have any of the following types of debt?

\begin{tabular}{|l|l|l|l|l|}
\hline & \multicolumn{1}{|c|}{ Item } & Yes & No & Not Sure \\
\hline A & Mortgage & & & \\
\hline B & Home equity loan & & & \\
\hline C & Car loan & & & \\
\hline D & Student loan & & & \\
\hline E & Credit card & & & \\
\hline F & Medical & & & \\
\hline G & Other & & & \\
\hline
\end{tabular}

\section{Credit}

13. Thinking about your current financial situation, how would you describe your level of debt?

Major problem Minor problem Not a problem

14. Credit Card companies only approve credit limits that an individual is able to afford

True False Not Sure

15. Approximately $10 \%$ of an individual's credit score is determined by their payment history.

True False Not Sure

16. Late payments on bills are a minor problem or no problem at all when seeking a home loan.

True False Not sure

17. Two people can purchase the same item and still pay vastly different amounts.

True False Not Sure

18. When you use a credit card you are borrowing money from a bank.

True False Not Sure 
19. Your credit history has no effect on your ability to get a job or rent an apartment.

\section{True False Not Sure}

20. Which of the following statements best describes your right to check your credit history for accuracy?

a. All credit reports are the property of the U.S. Government and access is only available to the FBI and Lenders.

b. You can only check your record for free if you are turned down for credit based on a credit report.

c. Your credit record can be checked once a year for free.

d. You cannot see your credit record.

21. If your credit card is stolen and the thief runs up a total debt of $\$ 1,000$, but you notify the issuer of the card as soon as you discover it is missing, what is the maximum amount that you can be forced to pay according to Federal law?
a. Nothing
b. $\$ 50$
c. $\$ 500$
d. $\$ 1,000$

22. In the past six months, I did not have to pay any late charges on my credit accounts.

True False Not Sure

23. Interest Rates and fees are about the same on all credit cards.

True False Not Sure

\section{Budgeting}

24. I balance my checkbook every month.

$\begin{array}{ccccccc}1 & 2 & 3 & 4 & 5 & 6 & \begin{array}{c}7 \\ \text { Never }\end{array} \\ & & & & & \text { Always }\end{array}$

25. Do you currently...? 


\begin{tabular}{|l|l|l|l|l|}
\hline & Item & Yes & No & Not Sure \\
\hline A & Stick to a monthly budget & & & \\
\hline B & Have a formal, written financial plan & & & \\
\hline C & Have a will & & & \\
\hline D & Have a living will (also known as a health care directive) & & & \\
\hline
\end{tabular}

26. Do you currently save money on a regular basis? Please do not include retirement plans offered by your employer?

Yes No Not Sure

27. Do you have an "emergency savings" fund or money that you keep in reserve for unexpected expenses, like a big car repair, or in case you were to stop receiving income for any reason?

Yes No Not Sure

28. An individual's budget should not be affected by their long-term financial goals.

True False Not Sure

29. A good budgeting approach is to break monthly expenses between wants and needs

True False Not Sure

\section{Car Purchases}

30. Most states require car owners to purchase auto insurance coverage.

True False Not Sure

31. If you have caused an accident, which type of automobile insurance would cover damage to your own car?
a. Term
b. Collision
c. Comprehensive
d. Liability

32. If I can't afford my car payments, I can voluntarily surrender my car to get out of the loan.

True False Not Sure

33. Invoice price is the price you pay for a car

True False Not Sure 
34. Financing a car purchase requires using the car manufacturer's financing programs

True False Not Sure

35. Leasing a car is a good option when you expect to put more than 15,000 miles on the car each year.

\section{True False Not Sure}

36. On average, a new car loses $20 \%$ of its value when you drive it off the lot.

True False Not Sure

37. One way to lower the price of car insurance is to lower your deductibles.

\section{True False Not Sure}

\section{Home Ownership}

38. After reviewing your financial information, lenders will only approve a mortgage with a monthly payment you can afford to pay.

\section{True False Not Sure}

39. The deduction of mortgage interest is a tax advantage of home ownership.

True False Not Sure

40. The deduction of real estate taxes (i.e., property taxes) is a tax advantage of home ownership.

True False Not Sure

41. The deduction of home improvements is a tax advantage of home ownership.

True False Not Sure

42. Closing costs are tax deductible in the year of your home purchase.

True False Not Sure

43. A reverse mortgage is a home mortgage in which the lender makes monthly payments to you, rather than you making monthly payments to the lender.

True False Not Sure 
44. In a period of rising market rates of interest, ARMs are more attractive than fixed rate mortgages.

True False Not Sure

\section{Investing}

45. Financial experts recommend having an emergency fund that is equal to 3-6 months' worth of living expenses

True False Not Sure

46. You should keep enough in your savings account to cover 3 months of expenses

True False Not Sure

47. I have a savings account at a financial institution.

True False Not Sure

48. If you had a savings account at a bank, which of the following would be correct concerning the interest that you would earn on this amount?
a. Sales tax may be charged on the interest that you earn.
b. You cannot earn interest until you pass your $18^{\text {th }}$ birthday.
c. Earnings from savings account interest may not be taxed.
d. Income tax may be charged on the interest if your income is high enough.

49. Many people put aside money to take care of unexpected expenses. If John and Jenny have money put aside for emergencies, in which of the following forms would it be of LEAST benefit to them if they needed it right away?
a. Stocks
b. Savings account
c. Invested in a down payment on the house
d. Checking account

50. In general, investments that are riskier tend to provide higher returns over time than investments with less risk. Please select one response.

\section{True False Not Sure}

51. What is a reasonable average of annual return that can be expected from a broadly diversified U.S. stock mutual fund over the long run? 
$5 \%$

$10 \%$

$15 \%$

$20 \%$

$25 \%$

Not sure

52. Over the past 20 years in the U.S., the best average returns have been generated by.... Please select one response.

\section{Stocks}

Money Market accounts

Bonds

CDs

Precious metals

Not sure

53. In general, if interest rates go down, then bond prices... Please select one response

Go down

\section{Go up}

Are not affected

Not sure

54. Compound Interest is when only the amount of money deposited earns interest.

True False Not Sure

55. If you buy a company's stock..... Please select one response

\section{You own part of the company}

The company will return your original investment to you with interest

You have lent money to the company

You are liable for the company's debts

Not sure

\section{Retirement}

56. In general, how much thought have you given to your own retirement?

A great deal of thought

Some thought

Not too much thought

No thought at all 
57. At what age do you think you will retire? Your best guess is fine.

49 or younger

50 to 59

60 to 69

70 to 79

80 or older

Will never retire

Not sure

58. Not including Social Security taxes or employer-provided money, have you personally saved any money for retirement? These savings could include money you personally put into a retirement plan at work?

\section{Yes No Not Sure}

59. Based on what you know about your health, your family history, and other factors, until what age do you expect to live? Your best guess is fine.

49 or younger

50 to 59

60 to 69

70 to 79

80 to 89

90 to 99

100 or older

Not sure

60. Below is a list of several possible sources of income in retirement. Which of these do you think will provide you (and your spouse) with the LARGEST share of income in retirement?

a. An employer-sponsored retirement savings plan, such as a 401(k), tax-deferred annuity or 403(b), 457 thrift savings, money purchase, or profit-sharing plan.

b. Other personal savings or investments, not in a work-related retirement plan, such as individual IRAs, mutual funds, stocks, CDs, or annuities

c. An employer-provided traditional pension or cash balance plan, with the benefit typically based on salary and years or service 

d. Social Security
e. Employment
f. The sale or refinancing of your home
g. Something else (Please specify)
h. Not sure

61. How confident are you that, when you retire, Social Security system will provide you with benefits of at least equal value to the benefits received by retirees today?

Very confident

Somewhat confident

Not too confident

Not at all confident

62. How confident are you that, when you retire, you will have saved enough money to afford a comfortable lifestyle in retirement?

Very confident

Somewhat confident

Not too confident

Not at all confident

63. Retirement income paid by a company is called:
a. Rents and profits
b. Social Security
c. $401 \mathrm{k}$
d. Pension

64. When an employee retires, the money they withdraw from their traditional $401(\mathrm{k})$ plan is subject to federal income taxes.

True False Not Sure 